\title{
Article \\ The Impact of Foreign Direct Investments and Economic Growth on Environmental Degradation: The Case of the Balkans
}

\author{
Aleksandra Pavlović ${ }^{1, *(D)}$, Milica Njegovan ${ }^{1}$ D, Andrea Ivanišević ${ }^{1}$, Mladen Radišić $^{1}$ (D), Aleksandar Takači ${ }^{2}$, \\ Alpar Lošonc ${ }^{1}$ and Sebastian Kot ${ }^{3,4, * \mathbb{D}}$
}

1 Faculty of Technical Sciences, University of Novi Sad, Novi Sad 21000, Serbia; njegovanmilica@yahoo.com (M.N.); andreai@uns.ac.rs (A.I.); mladenr@uns.ac.rs (M.R.); alpar@uns.ac.rs (A.L.)

2 Faculty of Technology, University of Novi Sad, Novi Sad 21000, Serbia; stakaci@tf.uns.ac.rs

3 The Management Faculty, Czestochowa University of Technology, Armii Krajowej 19B, 42-201 Częstochowa, Poland

4 Faculty of Economic and Management Sciences, North-West University, Vaal Triangle Campus, P.O. Box 1174, Vanderbijlpark 1900, South Africa

* Correspondence: pavlovic.di8.2018@uns.ac.rs (A.P.); sebacat@zim.pcz.czest.pl (S.K.); Tel.: +381-66-250-390 (A.P.)

Citation: Pavlović, A.; Njegovan, M.; Ivanišević, A.; Radišić, M.; Takači, A.; Lošonc, A.; Kot, S. The Impact of Foreign Direct Investments and Economic Growth on Environmental Degradation: The Case of the Balkans. Energies 2021, 14, 566. https:// doi.org/10.3390/en14030566

Received: 17 November 2020

Accepted: 18 January 2021

Published: 22 January 2021

Publisher's Note: MDPI stays neutral with regard to jurisdictional claims in published maps and institutional affiliations.

Copyright: (c) 2021 by the authors. Licensee MDPI, Basel, Switzerland. This article is an open access article distributed under the terms and conditions of the Creative Commons Attribution (CC BY) license (https:/ / creativecommons.org/licenses/by/ $4.0 /)$.

\begin{abstract}
The aspiration of this study was to examine the impact of foreign direct investments (FDI) and economic growth on environmental degradation in the Balkans for the period 1998-2019. Balkan countries were classified into two groups, high income countries (HIC) and upper-middle income countries (UMIC). Thus, two hypotheses have been set. The effect of FDI on environmental degradation was observed through pollution haven hypothesis (PHH). To examine that connection, we used Pearson correlation for all countries, HIC and UMIC. Furthermore, the impact of economic growth on environmental degradation was tested through the environmental Kuznets curve (EKC) hypothesis. For that purpose, polynomial linear regression was applied. In order to examine the dependence of environmental degradation in relation to all predictors in the model, a multivariate linear regression was used. PHH was confirmed in Serbia, Albania, Croatia, Romania, and Bulgaria, the Balkans as a whole, and HIC, and the EKC hypothesis was rejected. This paper represents a contribution to a very scarce number of studies regarding the impact of FDI and economic growth on the environment in the Balkans, as a whole. The results of this study can be useful to policy makers in the terms of inducting stricter environmental rules.
\end{abstract}

Keywords: foreign direct investments; environmental degradation; pollution haven; environmental Kuznets curve; Pearson correlation; polynomial linear regression; multivariate linear regression

\section{Introduction}

The tendencies of many countries towards economic progress, which involves attracting foreign direct investments (FDI), are often in conflict with increasingly demanding requirements for pollution control at both local and global levels. Achieving the balance between these tendencies has become an area of growing concern to ecological economists and it has been particularly intensified in the countries that do not traditionally export their capital, that is, countries that do not accumulate enough financial capital for domestic investments. There is a large number of researches that have dealt with the issue of FDI and their impact on economic growth. Most studies have shown a positive and significant link between FDI and economic growth [1-5]. Thus, it can be assumed that FDI growth significantly contributes to the growth of the country's GDP. The question of importance for this paper is whether both mentioned economic parameters have an impact on the $\mathrm{CO}_{2}$ 
emissions growth. Wang and Luo [6] addressed the impact of FDI on environmental degradation and concluded that the level of government involvement, economic development, and optimization of industrial structure contribute to improving environmental quality, while FDI intensifies environmental degradation.

FDI has a broad range of definitions, such as "net inflows or outflows as a percentage of GDP", "limited foreign capital", and the like, and one of them is that FDIs are a form of capital transfer, in which case an owner of the capital (foreign investor) invests the capital in the host country (foreign company) so that the foreign company can become an integral part of the economy of the country from which the capital is invested, proportionally to the funds invested by the foreign investor [7]. It is assumed that these investments are directed from the countries with a surplus of free capital and shortage in the cheap labor force to the countries with less free capital and an abundance of cheap labor. However, the reality is completely different and it is the most developed countries in the world that have the highest FDI inflow [8], which is not surprising because those countries are characterized by good infrastructure, stable political and legal system, high standard of living, open market, etc. On the other hand, it is easier to define GDP. Thus, GDP is a widely used measurement of economic growth and it represents the market value of all final goods and services produced by a country within a given period of time [9]. It is the most important macroeconomic variable, indicates the state of an economy and measures the economic strength of a country [10].

Domestic and foreign economic activities that drive economic growth and development contribute to environmental pollution because they produce greenhouse gases (GHGs) emissions [11] which have negatively affect global warming. The most well-known GHGs are carbon dioxide $\left(\mathrm{CO}_{2}\right)$, which is a result of burning fossil fuels, methane $(\mathrm{CH} 4)$ that is mainly produced due to livestock farming, nitrogen dioxide (NO2) resulting mainly from some industrial processes, the application of nitrogen fertilizers, as well as the combustion of fossil fuels, hydrofluorocarbons, perfluorocarbons, and sulfur hexafluoride (SF6), which are artificial gases. Given $\mathrm{CO}_{2}$ 's causal influence on ecological degradation [12-14], scientists in the field of ecological economics very often refer to it as a representative of GHGs in scientific research.

The goal of this paper is to study the impact of FDI and GDP on $\mathrm{CO}_{2}$ emissions, which has been quite neglected in the world and especially in such a closely related group of countries in the Balkans. In order to achieve this goal, our paper deals with several issues.

The first objective was to analyze the impact of FDI on $\mathrm{CO}_{2}$ emissions in ten Balkan countries to find out if PHH that often appears as a subject of verification in scientific ecological literature is valid for the Balkan countries. The Balkan countries are economically, culturally, and spatially connected. In addition, all of them have a GDP per capita that is below the European average [15], and all of them see the key to their economic growth in FDI. According to the latest United Nations Commission for Trade and Development's (UNCTAD) classification [16], Slovenia, Croatia, Greece, Bulgaria and Romania are the EU Member States and belong to the group of developed economies. On the other hand, the following five countries: Serbia, Albania, Montenegro, and Northern Macedonia are candidates for EU membership while Bosnia and Herzegovina is a potential candidate, and this is why the United Nations (UN) has classified these five countries as transition economies.

The second objective was to test the environmental Kuznets curve (EKC) hypothesis, which is also widely accepted in the literature on environmental economics, in order to determine the nature of the relationship between GDP and $\mathrm{CO}_{2}$ emissions on the example of the previously mentioned countries. The World Bank no longer classifies economies as 'developed' or 'developing', but classifies them based on their income level [17].

Bearing in mind the above mentioned and taking into account that Balkan countries are not equally developed, we have used the official classification presented by the World Bank, which is also the focus of our attention in this paper, when presenting the summary review of $\mathrm{CO}_{2}$ emission per capita in them as well as throughout the manuscript. According to this classification, Romania, Croatia, Greece, and Slovenia are high income countries 
(HIC), while Bulgaria, Serbia, Montenegro, Bosnia and Herzegovina, and North Macedonia are upper-middle income countries (UMIC).

The rest of the study is arranged as follows. The second part provides an overview of the relevant literature with hypotheses. The third part presents an overview of the FDIs and environmental pollution in the observed countries as well as the summarized data on environmental degradation with respect to the income groups. The fourth part explains the methodology, and its subsections include the model, data, variables, data analysis, and results. The fifth part includes a discussion, and the conclusion and suggestions are given in the last part.

\section{Literature Review and Hypotheses}

This part of the paper offers insight into the relevant existing scientific research focused on the relationship between FDI, economic growth, and environmental degradation. It also contains the literature concerning energy consumption (EC) using the examples of the Balkan and non-Balkan countries.

The results of empirical research concerning the debate over whether foreign investors contribute to the creation of pollution halos or pollution havens in host countries are mixed and often contradictory. Since the world market has become a 'global village', more fierce is the competition between MNCs, which, due to strict environmental regulations and high costs of pollution, often 'flee' to countries with less stringent regulations and costs and bring numerous benefits and spread negative effects on the environment to the host countries [18]. However, foreign investors can also bring about positive effects in the host countries in terms of pollution reduction. These two phenomena are known in environmental literature as pollution haven and pollution halo hypotheses [19]. Contrary to many critical attitudes towards FDI and their negative impact on sustainable development and environmental protection, neoliberal economists claim that MNCs contribute to sustainable development as they appear as the creators and owners of modern and cleaner technology [20].

Thus, many authors [21-24] have found evidence for the pollution halo hypothesis in different countries. On the other hand, there are a large number of studies [25-29] that confirm the existence of the pollution haven hypothesis $(\mathrm{PHH})$ in the observed countries. Moreover, there are studies in which both hypotheses have been confirmed. This way, for example, research conducted by Solarin and Al-mulali [30] found that FDI helped in reducing environmental degradation in developed countries (pollution halos), and encouraged it in developing countries (pollution havens).

Alshubiri and Elhedad [31] showed that the link between foreign finance and environmental quality was inverted U-shaped in OECD countries. Therefore, the initial impact of foreign finance was negative but after a certain point, the observed indicators affected the reduction in $\mathrm{CO}_{2}$ emission. Marques and Caetano [32] observed 21 countries with Greece classified in the high-income group, and Bulgaria, Croatia, and Romania classified in the middle-income group and concluded that FDI contributed to the reduction in $\mathrm{CO}_{2}$ emission in high-income countries, and in middle-income countries the situation was more complex. In these countries, FDIs first produced the pollution haven effect, but in the long run, they reduced the $\mathrm{CO}_{2}$ emissions. They indicated the ability of countries to adopt new technologies brought by foreign investors as a key factor in reducing degradation.

Therefore, between these two contradictory hypotheses, we prefer the pollution haven when it comes to the Balkans. Thus, we can anticipate:

Hypothesis (H1). Pollution haven hypothesis (PHH): As FDIs increase, $\mathrm{CO}_{2}$ emissions in the host country also increase (investors from countries with strong legislation in the field of environmental protection seek shelter in the countries with weaker legislation).

The relationship between the economic progress of countries and $\mathrm{CO}_{2}$ emission has long been a focus of attention in economics, and the results of the research are not always explicit. For example, Chang [33] concluded that China's economic growth affected the increase in $\mathrm{CO}_{2}$ emissions. Sallahudin and Gow [34] found no significant relationship 
between economic growth and $\mathrm{CO}_{2}$ emissions in Gulf Cooperation Council countries, which was not surprising given the fact that the economy of these countries is mostly based on the export of oil and natural gas, which does not cause GHG emission. Li et al. [35] used the example of post-capitalist countries such as Romania and Bulgaria to show that with the increase in GDP, $\mathrm{CO}_{2}$ emission will also increase. Hatzigeorgiou et al. [36] found that GDP Granger-caused $\mathrm{CO}_{2}$ emissions in Greece. The research conducted by Mitić et al. [37] in 17 transition countries showed that there was a long-run cointegrated relationship between $\mathrm{CO}_{2}$ emission and GDP. Petrović et al. [38] confirmed that there was a positive effect of population, GDP per capita, and energy intensity on $\mathrm{CO}_{2}$ emission in the EU countries, that is, that the economic growth increased pollution in the short run.

The already mentioned EKC hypothesis explains the connection between economic growth, most commonly expressed as GDP per capita, and the deterioration of the environment, most often expressed as $\mathrm{CO}_{2}$ emissions. Kuznets [39] originally developed the hypothesis of the existence of an inverted U-shaped linkage between income inequality and economic growth. Over time, environmental economists upgraded this original hypothesis into a new one, known as the EKC hypothesis, which emerged in the early 1990s with a study by Grossman and Krueger [40]. The model consists of the following-in the first phase of the GDP per capita growth, $\mathrm{CO}_{2}$ emission also increases to a certain level (turning point), and then, with the further growth in GDP per capita, $\mathrm{CO}_{2}$ emission starts decreasing, which is shown in the Figure 1. Until the turning point is reached, the economy of the country is pre-industrial, which means that the country is at a low-income level. After reaching the turning point, the economy of the country is characterized as industrial which means that it is at a middle-income level, and after that, the economy is post-industrial, that is, at a high-income level.

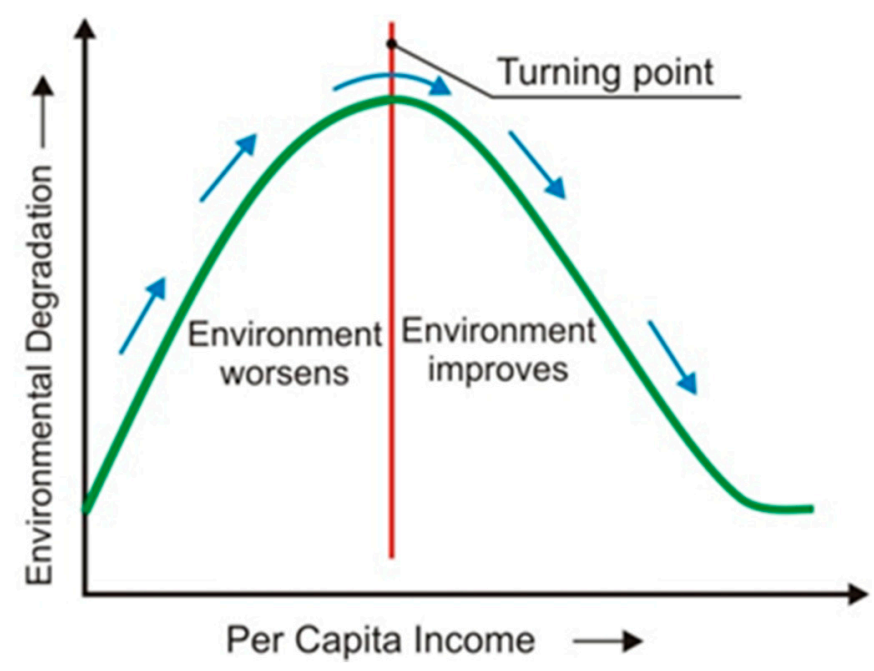

Figure 1. Environmental Kuznets curve (Authors' creation).

The results of EKC hypothesis tests vary. Some studies confirmed the hypothesis [28,41-43], while others did not find evidence to support it [22,44,45]. Furthermore, Mor and Jindal [46] showed that in the case of Greece and Slovenia, there was an inverted U-shaped connection, which means that the EKC hypothesis was proven for these two countries with a maximum turning point, while it was rejected in the case of Romania, Croatia, and Bulgaria. Contrary to this finding, Shahbaz et al. [47] confirmed the EKC hypothesis for Romania, and Kotroni et al. [48] rejected the EKC hypothesis for Greece. The results of the research showed the existence of U-shaped connections. Bozoklu et al. [49] did not determine the existence of a significant relationship between GDP per capita and $\mathrm{CO}_{2}$ emissions in Greece and concluded that the EKC hypothesis should not be relied upon and that we should not expect that economic growth would reduce pollution by itself. Mitić et al. [50] conducted a research that was, to their knowledge, a rarely studied subject but similar to ours. They 
investigated the relationship between $\mathrm{CO}_{2}$, industry, services, and gross fixed capital formation on the example of 9 Balkan countries (Albania, Bulgaria, Croatia, Greece, North Macedonia, Romania, Serbia, Slovenia, and Turkey). Their research showed that industry and gross fixed capital formation caused $\mathrm{CO}_{2}$ emissions, while services did not.

Hence, our intention is to test the stated hypothesis on the example of the Balkans:

Hypothesis (H2). EKC hypothesis: there is an inverse U-shaped link between GDP per capita and $\mathrm{CO}_{2}$ emissions i.e., with the growth of GDP per capita, $\mathrm{CO}_{2}$ emissions also increase to a certain point (turning point) after which the growth of GDP per capita leads to a reduction of $\mathrm{CO}_{2}$ emissions.

Although the energy sector has been considered to be very important for the social and economic development of a country, rapid globalization and economic growth lead to an increase in energy need, as well as in energy demand, thus creating a double problem: (i) energy supply at national level, and (ii) environmental pollution as a consequence of EC. Numerous studies have discovered a significant relationship between $\mathrm{EC}$ and $\mathrm{CO}_{2}$ emission $[44,51,52]$.

Sustainable development as a concordant relationship between economy and ecology, strives to preserve the natural wealth of the planet in order to maintain it for future generagions [53]. Thus, Ślusarczyk \& Kot [54] in their article discuss about a environmental solution adopted in Poland, wich refers to raising public awarness of the importance of reducing the usage of raw materials from non-renewable energy sources, such as oil found in fossil fuels, which is most commonly used in plastic bags production. Hussain et al. [55] conducted a study on a sample of major ASEAN (Association of Southeast Asian Nations) states, using a new neuro-fuzzy methodology, and concluded that there is a significant positive correlation between globalization and financial development and energy intensity. In addition to the usual renewable resources, countries need to move towards the use of innovative, hybrid renewable energy systems, in order to increase the share of renewable energy in the total energy sector [56].

The importance of renewable EC in relation to non-renewable EC, especially today, has been proven by numerous studies [57-60] which have determined that that renewable $\mathrm{EC}$ has an effect on the reduction of $\mathrm{CO}_{2}$ emissions. As the assumption is that EC is closely related to $\mathrm{CO}_{2}$ emissions, $\mathrm{EC}$ is taken as a control variable in our paper.

The classification of countries based on income groups has always been strongly related to $\mathrm{CO}_{2}$ emissions per capita [61]. Thus, Padilla and Serrano [62] analyzed $\mathrm{CO}_{2}$ emissions inequality in over a hundred selected countries around the world. The authors classified the observed countries according to the official World Bank classification into high income, middle income (upper and lower), and low income countries. The countries of ex-Yugoslavia (Bosnia and Herzegovina, Croatia, North Macedonia, Montenegro, Serbia, and Slovenia) were among MIC countries, and Greece was among HIC countries. The decline in $\mathrm{CO}_{2}$ emission inequality per capita was mainly the result of the decline in inequality within certain income groups, which is especially related to the MICs.

\section{Carbon Emissions in the Balkans and an Overview of the Situation and Trends of Foreign Investments}

Balkan countries are most certainly on their way to economic prosperity and environmental sustainability, but it is still a rocky road. Poverty, unresolved political issues, imprecise laws in the field of environmental protection, brain drain and alike are just some of the problems that these countries are facing. There was an improvement in economic performances of the Balkan countries two decades ago and the international community improved its policy towards them in terms of trade, various aid programs, and opportunities for membership in the European Union. These countries believe that FDI is a chance to achieve economic growth, which is why they compete to attract as many foreign investors as possible. At the same time, the environmental situation is not as expected. The trends of foreign investment inflows are quite uneven, which can be seen in Figure 2, and the 
situation is the same in the case of $\mathrm{CO}_{2}$ emissions trends, although they seem to be more uniform, as presented in Figure 3.

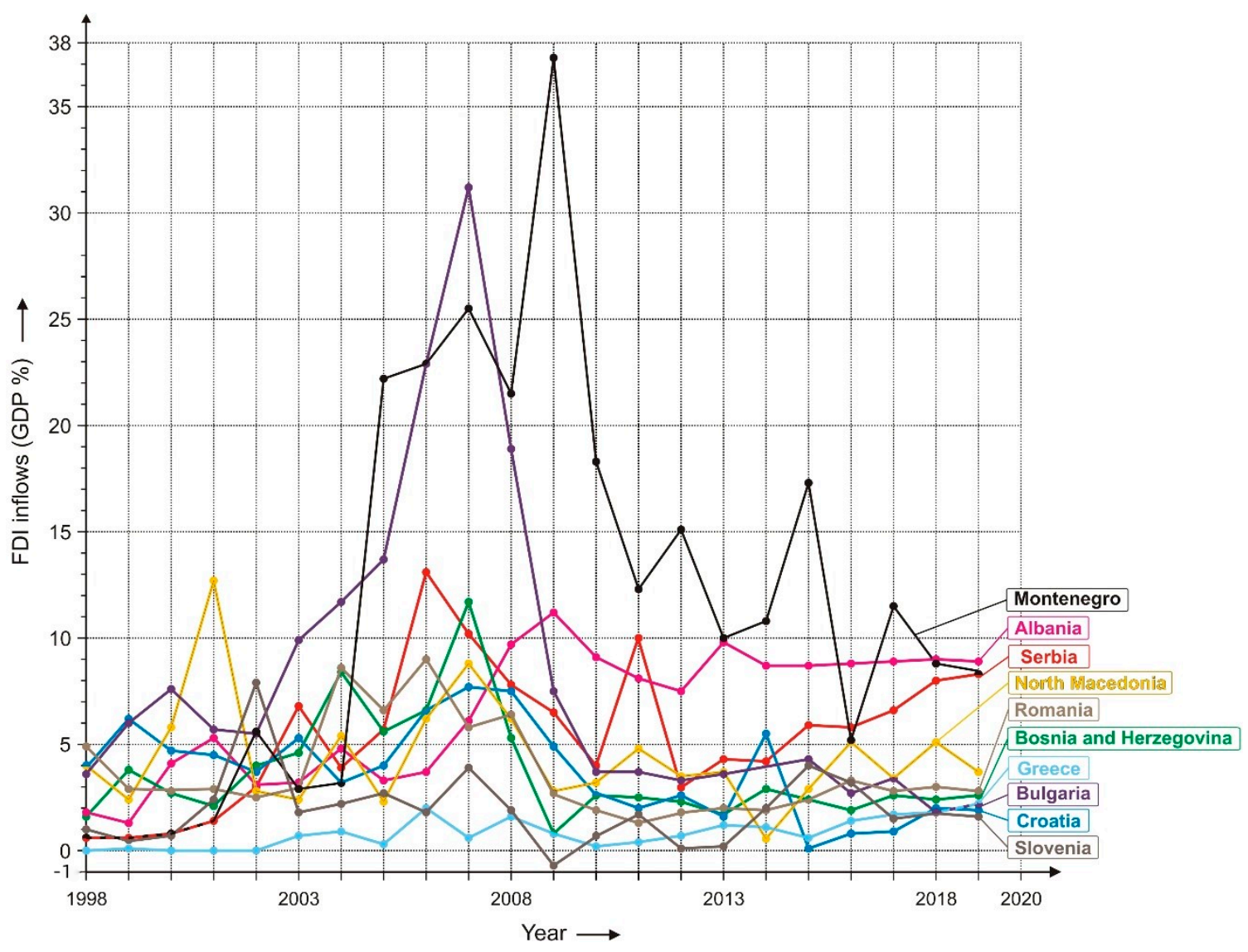

Figure 2. FDI inflows in ten Balkan countries (1998-2019) (Authors' creation).

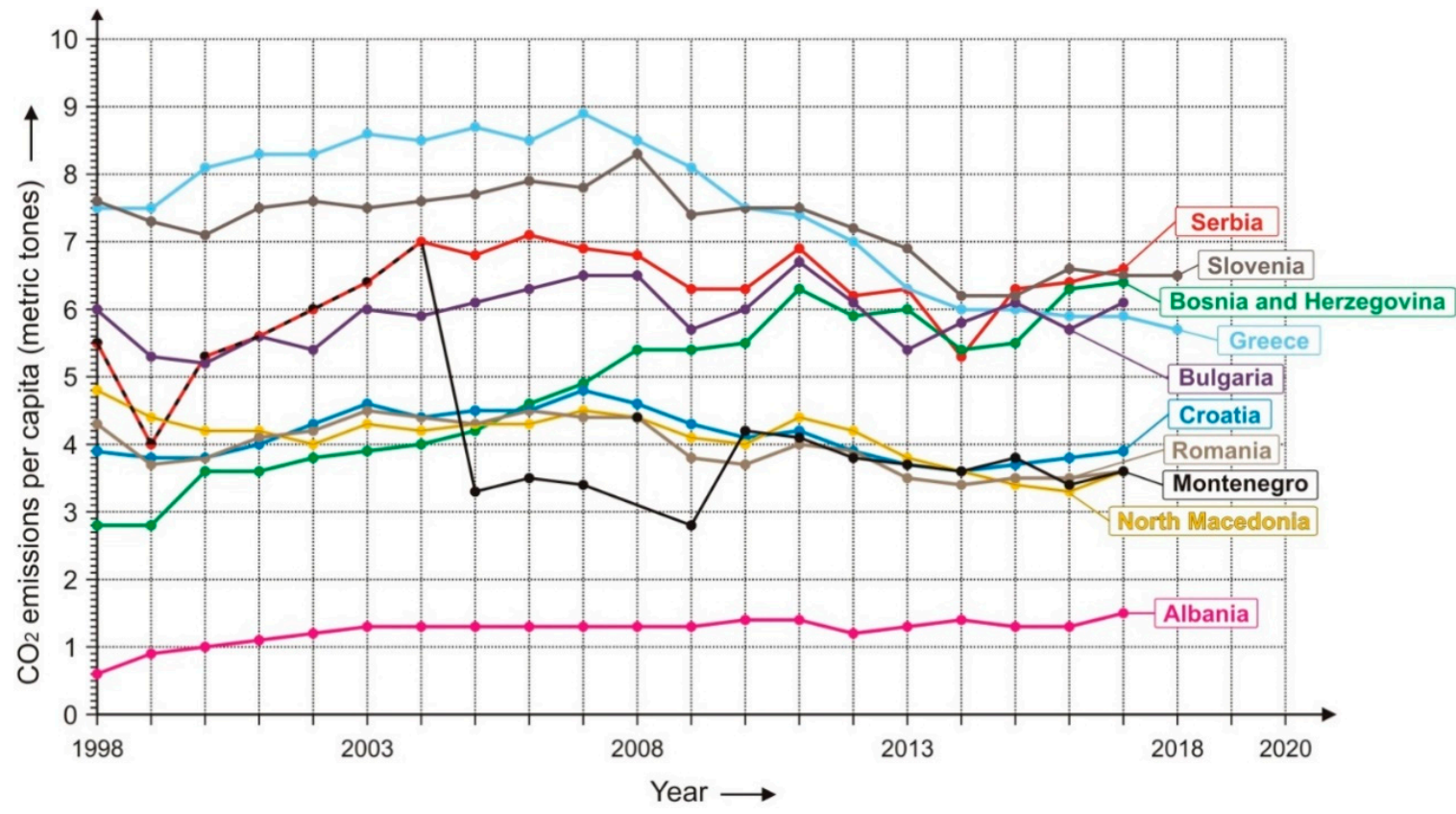

Figure 3. $\mathrm{CO}_{2}$ emissions per capita in ten Balkan countries (1998-2019) (Authors' creation).

Two decades ago, Serbia could not be complimented on a large number of foreign investors who were willing to invest in it. Not before 2002 has there been a growing trend 
of FDI inflows, and in 2006 this inflow was the largest, 13.10\% of GDP, but in 2011 and onwards, a declining trend has been noted. FDI inflows in Albania have been quite uneven, with frequent tendencies to rise and fall. The largest amount of FDI inflows was recorded in 2009, 11.20\% of GDP, while in 2008 and 2010, a significant increase of the inflows was recorded. As far as FDI inflows are concerned, there were slight ups and downs in Bosnia and Herzegovina until 2007, when FDI inflows were as high as 11.70\% of GDP. After 2007, FDI inflows dropped significantly to as much as $0.80 \%$ of GDP in 2009 , and after that, the growth trend was recorded again with mild declines. In Croatia, FDI inflows in 1998 amounted to $3.90 \%$ of GDP, in 2007, they reached the highest value of $7.70 \%$ of GDP, and after that, there was a downward trend with occasional growth. In 2001, North Macedonia recorded a three times higher increase in FDI inflows compared to 1998, as much as $12.70 \%$ of GDP, as well as a sharp decline of about 25 times less until 2014 when the value of FDI inflows was only $0.50 \%$ of GDP, which means that the country's economy has not recovered yet from the sharp decline, and the authorities should try to attract more foreign investors through various measures and programs. Compared to other Balkan countries, Greece has had a weak FDI inflow. From 1998 to 2002, there was almost no inflow of FDI, followed by an increase in inflows until 2006, when the largest inflow of FDI, 2\% of GDP, was recorded, followed by a decline with occasional mild growth. The FDI inflow in Romania was the highest in 2006, 9\% of GDP, and by 2014 this amount significantly reduced to $1.90 \%$ of GDP, which was almost five times less than in 2006. From 1998 to 2007, the level of FDI inflows in Bulgaria increased almost nine times to as much as 31.20\% of GDP, and from 2007 to 2014, it decreased by about 16 times to only $1.90 \%$ of GDP, which is a sharp decline. From 1998 to 2005, FDI inflows in Montenegro were negligible compared to the years that followed, which is not surprising given its separation from Serbia in 2006. As an independent state, Montenegro managed to attract most foreign investors and thus became the leader in FDI inflows in the region. This country had a record inflow of FDI in 2009, 37.30\% of GDP, and by 2014 , that amount dropped to $10.80 \%$ of GDP, which was again excellent compared to the countries in the region. Until 2002, Slovenia did not have significant FDI inflows, and in 2002, this inflow increased to $7.90 \%$ of GDP, which was almost eight times higher than in 1998. This was followed by a downward trend in FDI so that in 2009 FDI inflows were negative, $-0.70 \%$ of GDP. After a sharp drop in FDI inflows, the country's economy began to recover, recording larger but not very significant FDI inflows.

Serbia is one of the most polluted Balkan countries. The trend of $\mathrm{CO}_{2}$ emissions since 1998 has recorded steady growth with occasional declines. The largest increase in $\mathrm{CO}_{2}$ emissions was recorded in 2006, as much as 7.10 metric tons per capita, and after that, a mild downward trend has been observed. The trend of $\mathrm{CO}_{2}$ emissions in Albania is almost steady and slightly increasing. From 2003 to 2009, $\mathrm{CO}_{2}$ emissions amounted to 1.30 metric tons per capita, and since 2009 the trend has been slightly growing. Until 2011, the trend of $\mathrm{CO}_{2}$ emissions in Bosnia and Herzegovina was upward, when the highest $\mathrm{CO}_{2}$ emission in that country was recorded (6.30 metric tons per capita), followed by a slight decline to 5.90 metric tons per capita, then again by a slight increase in 2013 and a decline in 2014. From 1998 to 2000, as well as from 2012 to 2014, CO 2 emissions in Croatia were less than 4 metric tons per capita, while the amount of emission from 2001 to 2011 was higher than 4 metric tons per capita, and the highest in 2007. The $\mathrm{CO}_{2}$ emissions in North Macedonia, from 1998 to 2012, were more than 4 metric tons per capita, while in 2013 and 2014, there was a significant decline to 3.80 and 3.60 metric tons per capita, so authorities should take into account their environmental situation. Just like Serbia, Greece is a country with a high level of pollution and one of the largest emitters of $\mathrm{CO}_{2}$ in the world. The highest level of $\mathrm{CO}_{2}$ emissions in this country was recorded in 2007 (as much as 8.90 metric tons per capita) when it was followed by a downward trend. It can be presumed that the problems of environmental pollution in Greece are not so much related to foreign pollutants as to the environmental problems of the country itself. Also, it is probable that since this country is a popular tourist destination and vehicles that emit toxic gases are the main source of transport, air quality in this country is very poor. From 1999 to 2000, from 2009 to 2010, as 
well as from 2012 to 2014, the level of $\mathrm{CO}_{2}$ emissions in Romania was below 4 metric tons per capita, while in 2011 the level of emissions was 4 metric tons per capita, and in 1998, as well as from 2001 to 2008, the level of these emissions rocketed to over 4, with the highest recorded value in 2003 and 2006 (4.50 metric tons per capita). From 1999 to 2002, in 2004, 2009, from 2014 to 2015, the amount of $\mathrm{CO}_{2}$ emissions in Bulgaria was below 6 metric tons per capita, while in 2007 the highest amount of these emissions was recorded, as much as 6.80 metric tons per capita. Montenegro recorded the highest level of $\mathrm{CO}_{2}$ emissions in 2004, 7 metric tons per capita, but the adoption of environmental laws helped to reduce significantly the level of emissions to 3.40 in 2014. Given the high inflow of FDI compared to $\mathrm{CO}_{2}$ emissions, Montenegro rightly took the title of an ecological state in the region. Slovenia is similar to Serbia and Greece, a highly polluted Balkan country. The highest amount of $\mathrm{CO}_{2}$ emissions was recorded in 2008, as much as 8.30 metric tons per capita, while from 1998 to 2008 and from 2008 to 2012, this amount was below 8 metric tons per capita, and in 2014, it reduced to 6.20 metric tons per capita.

In order to see the average of $\mathrm{CO}_{2}$ emissions per capita in the HIC group and in the MIC group, the average of $\mathrm{CO}_{2}$ emissions for both groups is shown in the Figure 4 .

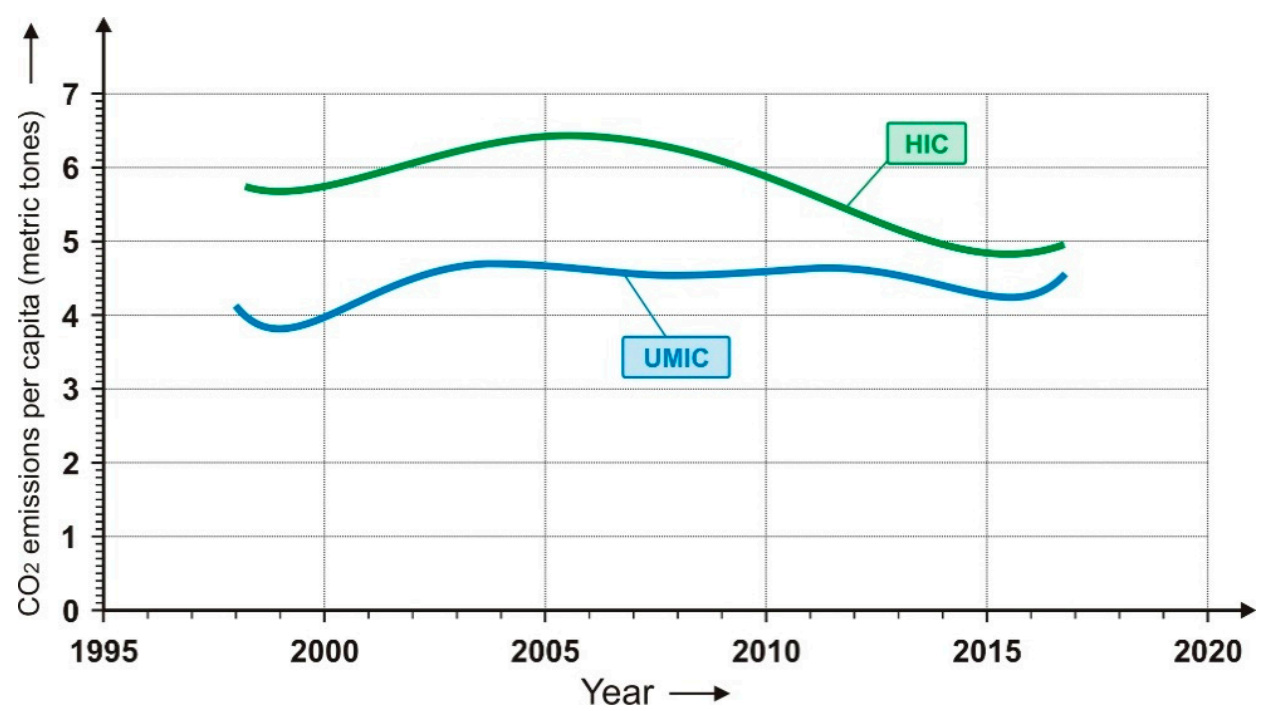

Figure 4. Average $\mathrm{CO}_{2}$ emissions per capita in HIC and UMIC groups (1998-2019) (Authors' creation).

The highest value of average $\mathrm{CO}_{2}$ emissions per capita in $\mathrm{HIC}$ was reached in 2007, with 6.48 metric tons, with occasional oscillations in values from 1998 to 2007. Constant growth was recorded from 2005 to 2007, after which the values oscillated. A significant decline occurred in 2018 when the lowest value was recorded, given that in 2017 the value was almost 5 metric tons and then dropped to 3.05 metric tons. Compared to HIC, the situation was somewhat different in UMIC. Constant growth was recorded from 2000 to 2004, and after a slight decline, there was again a constant growth from 2006 to 2008. After that, the values oscillated. The highest value was recorded in 2011, in the amount of almost 5 metric tons, while the lowest value in 1999 was around 3.57 metric tons.

\section{Data and Methodology}

\subsection{The Model}

Almost all EKC scientific studies use functional forms in which the results can be evaluated given the presence or absence of a turning point and the significance of its parameters [63], and standard EKC regression model usually has the following form in the literature (Equation (1)):

$$
\ln \left(E D_{i t}\right)=\alpha_{i}+\gamma_{t}+\beta_{1} \ln \left(Y_{i t}\right)+\beta_{2}\left(\ln \left(Y_{i t}\right)\right)^{2}+\beta_{k} \ln \left(Z_{i t}\right)+\varepsilon_{i t}
$$


where $i(i=1,2, \ldots, m)$ is the location index (country, region, etc.), $t(t=1,2, \ldots, n)$ time index, $E D$ ecological degradation (dependent-variable), $\alpha_{i}$ fixed location-specific effect, $\gamma_{t}$ fixed time effect, $\varepsilon_{i t}$ measurement error, $Y$ economic growth per capita, $Z$ other variables (e.g., investments, trade, imports, exports, population density, etc.), $\beta_{1}$ is the regression coefficient that stands next to the independent-variable $Y, \beta_{2}$ is the regression coefficient that stands next to the independent-variable square $Y$, and $\beta_{k}$ is the regression coefficient standing next to the independent-variable $Z$.

\subsection{Data and Variables}

The data for this study were collected from the website of the World Bank (World Bank-World Development Indicators) and the International Energy Agency (IEA) for the period from 1998 to 2019, on a sample of ten Balkan countries (Serbia, Albania, Bosnia and Herzegovina, Croatia, North Macedonia, Greece, Romania, Bulgaria, Montenegro, and Slovenia). Currently, the World Bank classifies all countries into four income groups: high, upper-middle, lower-middle, and low, and Gross National Income (GNI) per capita is used as a measure of income [64]. GNI per capita is expressed in US\$ and converted from local currency using the official WB Atlas method. According to the official classification of the World Bank, all observed countries are classified on an annual basis (US\$), into two categories (the table for this classification is given in the Appendix A-Table A1):

(i) HIC: Croatia, Greece, Romania and Slovenia, and

(ii) UMIC: Serbia, Albania, Bosnia and Herzegovina, North Macedonia, Bulgaria, and Montenegro, given that none of the observed Balkan countries belongs to lowermiddle or low-income categories.

In this study, the above-mentioned square model (1) will be used in the following form:

$$
\ln \left(\mathrm{CO}_{2 i t}\right)=\beta_{0 i}+\beta_{1 i} \ln \left(\mathrm{GDP}_{i t}\right)+\beta_{2 i}\left(\ln \left(\mathrm{GDP}_{i t}\right)\right)^{2}+\beta_{3 i} \ln \left(\mathrm{FDI}_{i t}\right)+\beta_{4 i} \ln \left(\mathrm{EC}_{i t}\right)+\varepsilon_{i t}
$$

where $\beta_{0 i}=\alpha_{i}+\gamma_{t}$.

$\mathrm{CO}_{2}$ will be taken as a dependent variable in the model as it is the most significant representative of ecological degradation. As the gross domestic product (GDP) is most responsible for the economic growth of a country, it will be taken as a proxy for economic growth, per capita. Thus, the independent variables in the model are GDP per capita, the square of GDP per capita, and net inflows of FDI. The control variable in the model will be the EC per capita since it is considered the largest cause of $\mathrm{CO}_{2}$ emissions [22,25]. Table 1 gives definitions of variables with their sources.

Table 1. Definitions of variables, type, and data sources.

\begin{tabular}{ccccc}
\hline Variable & Definition & Unit & Type & Source \\
\hline $\mathrm{CO}_{2}$ & $\mathrm{CO}_{2}$ emissions per capita & Metric tones & Dependent & IEA \\
$\mathrm{GDP}$ & GDP per capita (constant 2010) & \$US (Dollar) & Independent & WB \\
$\mathrm{GDP}^{2}$ & Square of GDP per capita & \$US (Dollar) & Independent & WB \\
FDI & Share of FDI in GDP & $\%$ (percent) & Independent & WB \\
EC & EC per capita & $\mathrm{Kg}$ of oil equivalent & Control & IEA \\
\hline
\end{tabular}

All data were transformed into natural logarithms to eliminate the influence of heteroskedasticity and reduce the influence of data fluctuation [65]. For GDP per capita and FDI variables, all data by years were available for all countries. However, for $\mathrm{CO}_{2}$ and EC variables, data for individual years were not available and it was done without them, so the number of observations was not constantly 22. For statistical data processing, Statistica, $\mathrm{R}$, and Microsoft Excel software packages were used.

\subsection{Data Analysis and Results}

The use of multivariate regression analysis of panels of data has a long tradition in the social and behavioral sciences. However, not enough attention has been paid to this analysis 
in the literature, and the number of studies using it for data panel analysis is small [66]. The above-mentioned multivariate regression model (2) was used for this study to examine the effect of independent variables (GDP, GDP ${ }^{2}, \mathrm{FDI}$, and $\left.\mathrm{EC}\right)$ on the dependent variable $\left(\mathrm{CO}_{2}\right)$. The basic EKC regression model is mostly square and as the only variable independent from the impact on environmental degradation, it considers the real income per capita and its square. However, income is not the only factor influencing environmental degradation, which is something that a large number of scientific studies agree about $[11,18,22,25]$. In addition to income, scientists in the field of ecological economics often introduce import and export, industrialization, investments, foreign investments, EC, electricity consumption, EC from renewable and non-renewable sources, etc. as factors that influence ecological degradation, and FDIs are considered to be the most significant factors of environmental degradation. In this study, the standard EKC model was extended with variables that are considered to have a significant impact on $\mathrm{CO}_{2}$ emissions in addition to GDP, namely FDI and EC (Equation (2)). Table 2 shows the descriptive statistics of the variables for all countries.

Table 2. Descriptive statistics.

\begin{tabular}{cccccc}
\hline Descriptive Statistics & $\mathbf{C O}_{\mathbf{2}}$ & GDP & GDP $^{\mathbf{2}}$ & FDI & EC \\
\hline Mean & 3.84 & 11.50 & 21.15 & 3.84 & 9.82 \\
Std. & 0.31 & 0.14 & 0.21 & 0.40 & 0.31 \\
Min & 2.50 & 11.22 & 20.70 & 3.09 & 8.59 \\
Max & 4.00 & 11.71 & 21.43 & 4.71 & 9.98 \\
Observations & 21.00 & 22.00 & 22.00 & 22.00 & 18.00 \\
\hline
\end{tabular}

Table 3 presents mean values, standard deviations, minimal and maximum values of variables for a period of 22 years. Mean values are ranked as shown in brackets.

The rank of means is quite inconsistent among countries, except for: Albania, when the rank of $\mathrm{CO}_{2}$ is compared to either GDP or EC's ranks; Greece and Slovenia, when the rank of $\mathrm{CO}_{2}$ is compared to GDP; Bosnia and Herzegovina and North Macedonia, when the rank of GDP is compared to EC; Montenegro, when the rank of $\mathrm{CO}_{2}$ is compared to EC.

In order to determine the trends for the dependence of GDP and $\mathrm{CO}_{2}$ emissions, polynomial linear regression model was used:

$$
\mathrm{CO}_{2}=\alpha_{0}+\alpha_{1} \mathrm{GDP}+\alpha_{2} \mathrm{GDP}^{2}+\ldots+\alpha_{n} \mathrm{GDP}^{n}, n \in N
$$

where $\mathrm{CO}_{2}$ is a dependent variable, GDP is independent variable, $\alpha_{1}, \alpha_{2}, \ldots \alpha_{n}$ are regression coefficients, and $n$ is polynomial degree.

For each country, the optimal degree of the model was found and presented in Table 4 . Moreover, multiple coefficients of determination were calculated for each country separately, for all countries together and for HIC and UMIC. A standard formula for this coefficient is:

$$
\mathrm{R}^{2}=\frac{\sum\left(\hat{y}_{i}-\bar{y}\right)^{2}}{\sum\left(y_{i}-\bar{y}\right)^{2}}
$$

where $\mathrm{R}^{2}$ is a multiple determination coefficient, $\hat{y}$ is the predicted value of the dependent variable, $\bar{y}$ the dependent variable mean, and $y$ is the dependent variable raw score. 
Table 3. Descriptive statistics with mean ranking.

\begin{tabular}{|c|c|c|c|c|c|c|c|c|}
\hline \multirow{2}{*}{ Country } & \multicolumn{4}{|c|}{$\mathrm{CO}_{2}$} & \multicolumn{4}{|c|}{ GDP } \\
\hline & Mean (Rank) & Std. & Min & Max & Mean (Rank) & Std. & Min & Max \\
\hline Serbia & $1.82(3)$ & 0.13 & 1.93 & 1.96 & $8.55(7)$ & 0.23 & 8.10 & 8.88 \\
\hline Albania & $0.19(10)$ & 0.20 & -0.51 & 0.41 & $8.16(10)$ & 0.31 & 7.52 & 8.56 \\
\hline $\begin{array}{l}\text { Bosnia and } \\
\text { Herzegovina }\end{array}$ & $1.54(5)$ & 0.26 & 1.03 & 1.86 & $8.36(8)$ & 0.25 & 7.87 & 8.74 \\
\hline Croatia & $1.41(7)$ & 0.09 & 1.28 & 1.57 & $9.50(3)$ & 0.14 & 9.21 & 9.71 \\
\hline $\begin{array}{c}\text { North } \\
\text { Macedonia }\end{array}$ & $1.41(8)$ & 0.10 & 1.19 & 1.57 & $8.35(9)$ & 0.18 & 8.07 & 8.64 \\
\hline Greece & $2.00(1)$ & 0.15 & 1.74 & 2.19 & $10.12(1)$ & 0.11 & 9.99 & 10.31 \\
\hline Romania & $1.39(9)$ & 0.12 & 1.22 & 1.74 & $8.94(4)$ & 0.29 & 8.47 & 9.40 \\
\hline Bulgaria & $1.78(4)$ & 0.07 & 1.65 & 1.92 & $8.72(6)$ & 0.27 & 8.24 & 9.11 \\
\hline Montenegro & $1.44(6)$ & 0.25 & 1.03 & 1.95 & $8.75(5)$ & 0.18 & 8.47 & 9.05 \\
\hline Slovenia & $1.98(2)$ & 0.08 & 1.82 & 2.12 & $10.02(2)$ & 0.13 & 9.74 & 10.21 \\
\hline \multirow{2}{*}{ Country } & \multicolumn{4}{|c|}{ FDI } & \multicolumn{4}{|c|}{ EC } \\
\hline & Mean (Rank) & Std. & Min & Max & Mean (Rank) & Std. & Min & Max \\
\hline Serbia & $1.42(4)$ & 0.90 & -0.51 & 2.57 & $7.65(5)$ & 0.10 & 7.43 & 7.79 \\
\hline Albania & $1.73(3)$ & 0.58 & 0.26 & 2.42 & $6.51(10)$ & 0.15 & 6.06 & 6.70 \\
\hline $\begin{array}{l}\text { Bosnia and } \\
\text { Herzegovina }\end{array}$ & $1.12(7)$ & 0.60 & -0.22 & 2.46 & $7.25(8)$ & 0.27 & 6.79 & 7.72 \\
\hline Croatia & $1.04(8)$ & 0.98 & -2.30 & 2.04 & $7.65(4)$ & 0.07 & 7.54 & 7.76 \\
\hline $\begin{array}{c}\text { North } \\
\text { Macedonia }\end{array}$ & $1.33(5)$ & 0.63 & -0.69 & 2.54 & $7.22(9)$ & 0.06 & 7.12 & 7.32 \\
\hline Greece & $-0.14(10)$ & 0.83 & -2.30 & 1.39 & $7.82(2)$ & 0.87 & 7.66 & 7.92 \\
\hline Romania & $1.17(6)$ & 0.52 & 0.26 & 2.20 & 7.47 (7) & 0.06 & 7.37 & 7.56 \\
\hline Bulgaria & $1.74(2)$ & 0.80 & 0.59 & 3.44 & $7.81(3)$ & 0.06 & 7.71 & 7.90 \\
\hline Montenegro & $1.97(1)$ & 1.25 & -0.51 & 3.62 & $7.55(6)$ & 0.13 & 7.34 & 7.79 \\
\hline Slovenia & $0.44(9)$ & 1.02 & -2.30 & 2.07 & $8.15(1)$ & 0.05 & 8.06 & 8.25 \\
\hline
\end{tabular}

Table 4. Multiple regression coefficients.

\begin{tabular}{ccc}
\hline Country & Degree of Polynomial Model & $\mathbf{R}^{\mathbf{2}}$ \\
\hline Serbia & 2 & 0.68 \\
Albania & 2 & 0.79 \\
Bosnia and Herzegovina & 1 & 0.91 \\
Croatia & 4 & 0.9 \\
North Macedonia & 6 & 0.9 \\
Greece & 2 & 0.88 \\
Romania & 2 & 0.53 \\
Bulgaria & 6 & 0.59 \\
Montenegro & - & - \\
Slovenia & 4 & 0.88 \\
All countries & 4 & 0.75 \\
HIC & 2 & 0.81 \\
UMIC & 6 & 0.65 \\
\hline
\end{tabular}

GDP in Serbia has a $U$ trend but is relatively weak $\left(\mathrm{R}^{2}=0.68\right)$. Albania has a constant slow growth of $\mathrm{CO}_{2}$ emissions, and the values are much lower compared to the other 
countries. In Bosnia and Herzegovina, there is a linear dependence between GDP and $\mathrm{CO}_{2}$ emissions and constant growth $\left(R^{2}=0.9\right)$. Croatia has several small peaks that approximate perfectly with a polynomial of the fourth degree. North Macedonia has a declining trend with mini peaks and it excellently approximates with a fifth degree polynomial. GDP in Greece has a $U$ trend but dependence as well when years are considered as independent variable and $\mathrm{CO}_{2}$ as a dependent variable $\left(\mathrm{R}^{2}=0.88\right)$. GDP in Romania has a $\mathrm{U}$ shape but $\mathrm{R}^{2}=0.53$. The GDP trend in Bulgaria is similar to that in Croatia and North Macedonia but it lacks a good polynomial model. GDP in Montenegro has an unusual trend with a sharp decline in 2005. Slovenia has the highest $\mathrm{CO}_{2}$ emissions and, similarly to Croatia, we have an approximation by a fourth degree polynomial $\left(R^{2}=0.88\right)$. In summary, it is obvious that there is no clear curve trend, which is shown in Figure 5, i.e., no curve in any of these countries fits the inverted U-shaped curve shown in Figure 1. For better clarity, we have shown the curve trends separately for each country in Appendix A (Figure A1).

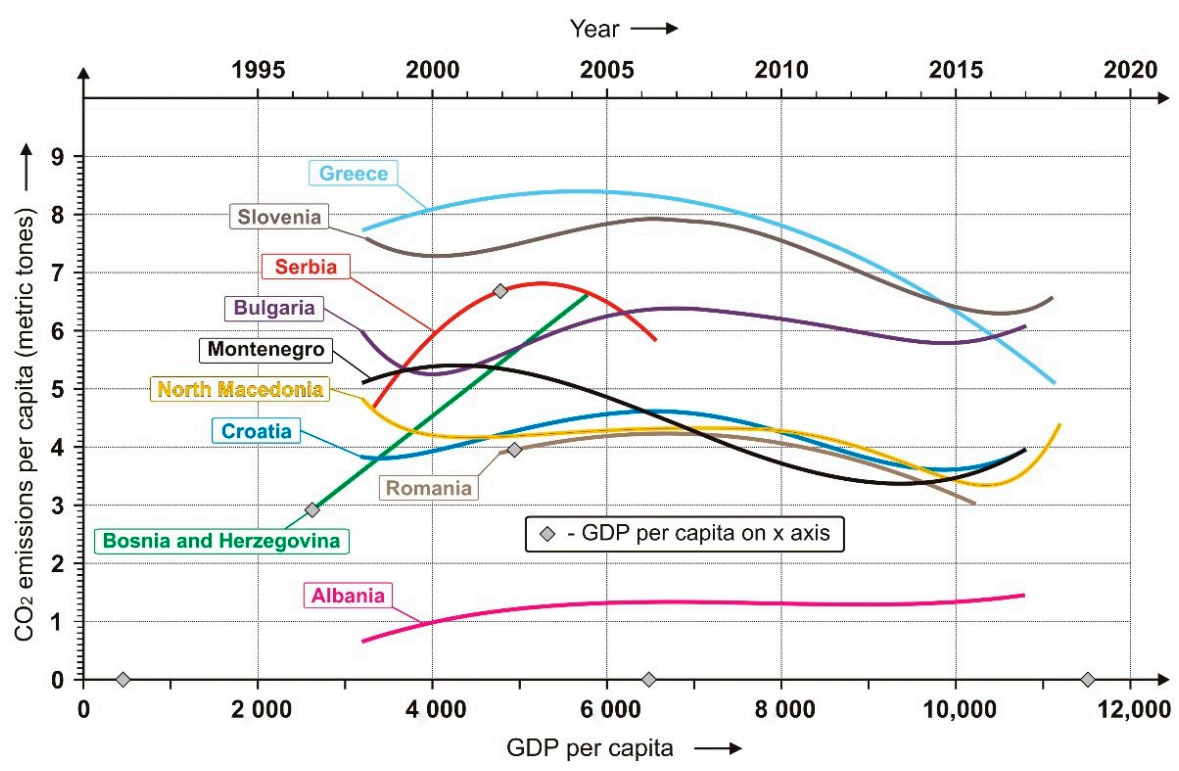

Figure 5. Relationship between $\mathrm{CO}_{2}$ emissions per capita and GDP per capita in ten Balkan countries (1998-2019) (Authors' creation).

All countries together have several small peaks, but there is no good polynomial approximation. The sum of HIC has a good trend $\left(R^{2}=0.88\right)$ when it is approximated by a polynomial of the second degree, but it does not act as a $U$ shape, more like decreasing and oscillating. The sum of UMIC has a slightly growing trend without a good approximation. All of this is shown in Figure 6.

The general conclusion is that the hypothesis $\mathrm{H} 2$ cannot be adopted because there are different trends in the region for dependence between GDP and $\mathrm{CO}_{2}$ emissions.

Based on the Pearson correlation coefficient $(\mathrm{R})$ between FDI and $\mathrm{CO}_{2}$ emissions given in Table 5, it can be concluded that there is a significant correlation in most countries, as well as for all the countries regarded as a whole.

Given the positive values of the Pearson correlation coefficient (R), the correlation between FDI and $\mathrm{CO}_{2}$ emissions is positive in all countries except Bosnia and Herzegovina, Greece, and Montenegro, for which the values of this coefficient are negative. Positive correlations are strong and statistically significant for Serbia, Albania, Croatia, Romania, and Bulgaria, all countries in total and developed countries (HIC), which means that $\mathrm{CO}_{2}$ emissions increase with the growth of FDI, confirming the pollution haven hypothesis (H1) for these countries. The negative correlation is strong and statistically significant only for Montenegro, which means that, with the growth of FDI, the $\mathrm{CO}_{2}$ emissions decrease, which would correspond to the pollution halo assumption for this country. 


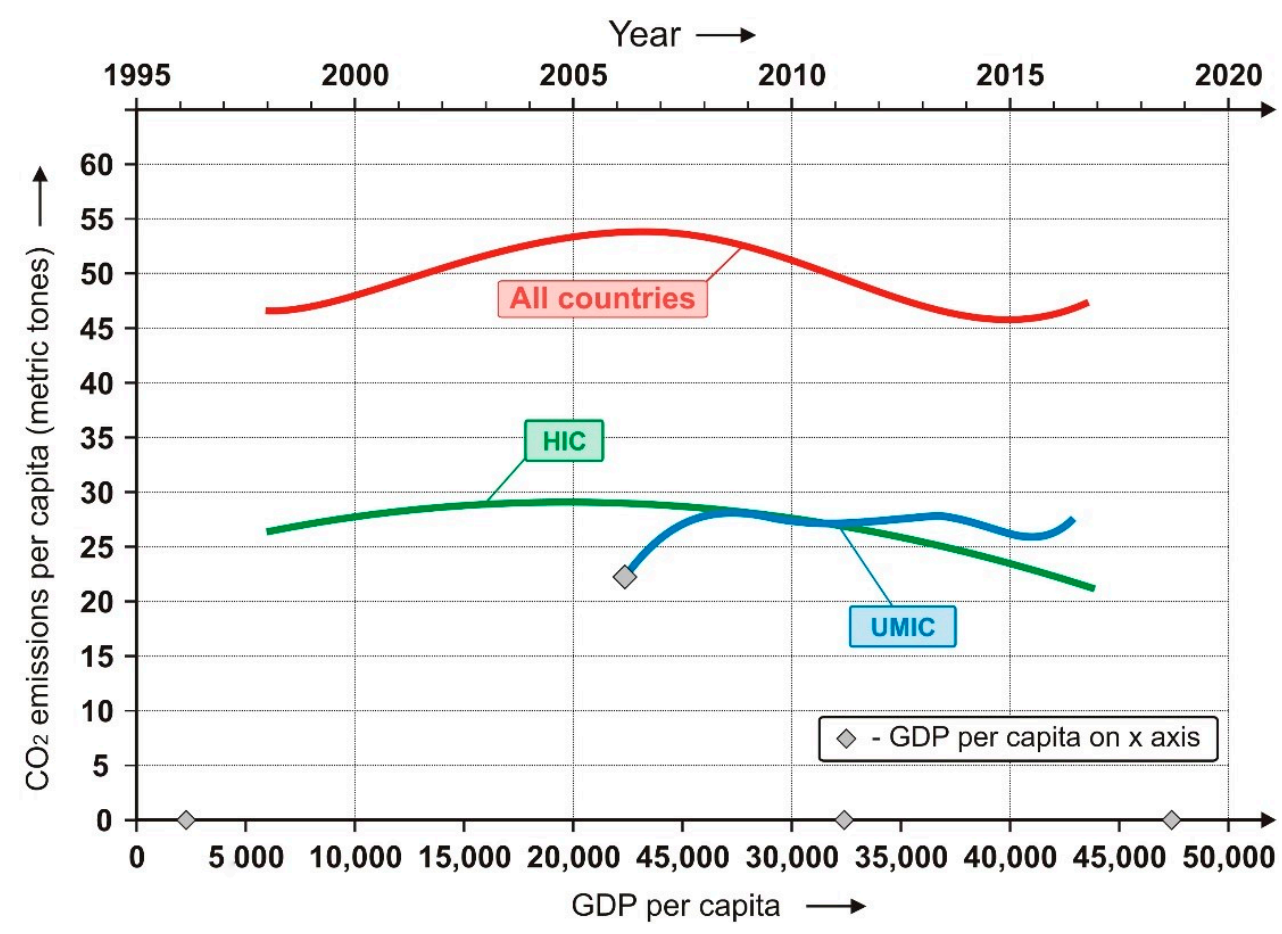

Figure 6. Relationship between $\mathrm{CO}_{2}$ emissions per capita and GDP per capita summary for all Balkan countries, and HIC and UMIC groups (1998-2019) (Authors' creation).

Table 5. Pearson correlation coefficient for FDI and $\mathrm{CO}_{2}$ emission presented per country and for all countries, HIC and UMIC.

\begin{tabular}{ccc}
\hline Country & Correlation Coefficient (R) & Confirmed Hypothesis \\
\hline Serbia & $0.76^{*}$ & $\mathrm{H} 1$ \\
Albania & $0.62^{*}$ & $\mathrm{H} 1$ \\
Bosnia and Herzegovina & -0.20 & $\mathrm{H} 1$ \\
Croatia & $0.56^{*}$ & \\
North Macedonia & 0.28 & $\mathrm{H} 1$ \\
Greece & -0.28 & $\mathrm{H} 1$ \\
Romania & $0.71^{*}$ & \\
Bulgaria & $0.54^{* *}$ & $\mathrm{H} 1$ \\
Montenegro & $-0.68^{*}$ & $\mathrm{H} 1$ \\
Slovenia & $0.27^{*}$ & \\
All countries & $0.60^{*}$ & \\
HIC & $0.69^{*}$ & 0.42 \\
UMIC &
\end{tabular}

Significant correlations with significance threshold are marked ${ }^{*} \alpha=0.01,{ }^{* *} \alpha=0.05$.

Table 6 shows a significant correlation between GDP and years, i.e., GDP has a constantly growing trend in all countries except Greece.

In other words, given the positive values of the Pearson correlation coefficient (R), the correlation between years and GDP is positive and statistically significant in all countries except Greece, for which the value of the correlation coefficient is negative.

By applying the method of multivariate linear regression, the coefficients of the model that preceded the corresponding independent variables in the model were obtained, as well as the coefficient of determination $\left(\mathrm{R}^{2}\right)$, both for each country individually and for all countries, as well as for HIC and UMIC $(p<0.01)$, and they are shown in Table 7. $\beta_{0}$ is a constant, $\beta_{1}$ is the coefficient standing next to the independent variable GDP, $\beta_{2}$ is the coefficient standing next to the independent variable $\mathrm{GDP}^{2}, \beta_{3}$ is the coefficient standing 
next to the independent variable FDI, and $\beta_{4}$ is the coefficient standing next to the control variable EC.

Table 6. Pearson correlation coefficient for years and GDP per country and all countries.

\begin{tabular}{cc}
\hline Country & Correlation Coefficient (R) \\
\hline Serbia & $0.97^{*}$ \\
Albania & $0.99^{*}$ \\
Bosnia and Herzegovina & $0.99^{*}$ \\
Croatia & $0.82^{*}$ \\
North Macedonia & $0.98^{*}$ \\
Greece & -0.15 \\
Romania & $0.98^{*}$ \\
Bulgaria & $0.98^{*}$ \\
Montenegro & $0.96^{*}$ \\
Slovenia & $0.87^{*}$ \\
All countries & $0.88^{*}$ \\
HIC & $0.70^{*}$ \\
MIC & $0.99^{*}$
\end{tabular}

Significant correlations with significance threshold are marked ${ }^{*} \alpha=0.01$.

Table 7. Multivariate linear regression fit results.

\begin{tabular}{ccccccc}
\hline Country & \multicolumn{2}{c}{ Variables } \\
\cline { 2 - 7 } & Constant & GDP & GDP & FDI & EC & $\mathbf{R}^{\mathbf{2}}$ \\
\hline Serbia & 0.0095 & 0.0085 & 0.0084 & 0.0020 & $\mathbf{0 . 0 2 5 2}$ & 0.9216 \\
Albania & $\mathbf{0 . 0 5 7 9}$ & $\mathbf{0 . 0 4 5 7}$ & $\mathbf{0 . 0 4 6 9}$ & 0.0004 & $\mathbf{0 . 0 2 8 0}$ & 0.9801 \\
Bosnia and Herzegovina & 0.0115 & 0.0101 & 0.0089 & 0.0084 & 0.0061 & 0.9604 \\
Croatia & 0.0002 & 0.0001 & 0.0001 & 0.0020 & $\mathbf{0 . 0 6 2 8}$ & 0.9604 \\
North Macedonia & 0.0002 & 0.0002 & 0.0002 & 0.0004 & $\mathbf{0 . 0 3 7 0}$ & 0.9604 \\
Greece & 0.0001 & 0.0001 & 0.0001 & 0.0023 & $\mathbf{0 . 0 3 3 0}$ & 0.9801 \\
Romania & $\mathbf{0 . 0 0 4 5}$ & $\mathbf{0 . 0 0 3 1}$ & $\mathbf{0 . 0 0 3 2}$ & 0.0005 & $\mathbf{0 . 0 3 3 4}$ & 0.9604 \\
Bulgaria & 0.0005 & 0.0011 & 0.0011 & 0.0001 & $\mathbf{0 . 0 3 4 1}$ & 0.9604 \\
Montenegro & 0.0500 & 0.0516 & 0.0517 & 0.0066 & $\mathbf{0 . 4 1 0 6}$ & 0.8464 \\
Slovenia & $\mathbf{0 . 0 0 2 0}$ & $\mathbf{0 . 0 0 2 4}$ & $\mathbf{0 . 0 0 2 3}$ & 0.0005 & $\mathbf{0 . 0 4 5 1}$ & 0.9409 \\
Sum for all countries & 0.0006 & 0.0004 & 0.0005 & 0.0004 & $\mathbf{0 . 0 3 1 3}$ & 0.9216 \\
Sum for HIC & 0.0000 & 0.0001 & 0.0001 & 0.0002 & $\mathbf{0 . 0 5 5 6}$ & 0.9604 \\
Sum for UMIC & 0.0008 & 0.0006 & 0.0006 & 0.0001 & $\mathbf{0 . 0 2 8 6}$ & 0.8836 \\
\hline
\end{tabular}

Note: Regression coefficients with significant values are bolded.

It can be concluded that the impact of $\mathrm{EC}$ on $\mathrm{CO}_{2}$ emissions is significant in all countries except Bosnia and Herzegovina, since the values of the coefficients $\beta_{4}$ in all countries, except Bosnia, are greater than 0.01 level of significance. The impact of GDP and $\mathrm{GDP}^{2}$ on $\mathrm{CO}_{2}$ emissions is significant in Albania, Romania and Slovenia.

\section{Discussion}

Here we would like to consider the following points.

First, Pearson correlation between FDI and $\mathrm{CO}_{2}$ emissions confirmed the hypotheses H1. Shelters of foreign polluters (pollution havens) are Serbia, Albania, Croatia, Romania, and Bulgaria, while Montenegro is not. On 20 September 1991, Montenegro adopted the 'Declaration on the designation of this republic as an ecological state' and numerous regulations which were aimed at reducing pollution. However, there are still certain problems, such as emissions from industry, energy, transport, and fuel combustion in the household sector. Technologies used in industry and power plants in Montenegro are inefficient and still represent a source of polluting emissions [67]. In summary, the H1 applies to all countries, so the Balkan countries are indeed shelters for foreign polluters. The findings are in line with the previous studies, such as Smarzynska and Wei [68], which 
was done on the example of 24 transition economies and confirmed the existence of $\mathrm{PHH}$ in Bulgaria, North Macedonia, Romania and Slovenia. Similarly, Cai et al. [69] tested the PHH between China and 19 developing economies, using a belt and road case study composed of $\mathrm{CO}_{2}$ emissions calculation contained in exports and imports. The study revealed that these economies, including Albania, Bulgaria, Bosnia and Herzegovina and Croatia, have become China's pollution shelters. Simeunčević [70] used data from 2000 to 2008 and conducted a research on the example of Serbia which proved that FDI had not contributed significantly to environmental degradation but had neither improved the environment. The conclusion is that 'dirty' FDIs are not a dominant form of foreign investments in this country although their presence is undeniable. Neutrality may be the result of a shorter period of observation. Our finding is in accordance with the findings of Mert et al. [29] which confirmed the existence of PHH in 27 European countries, including Bulgaria, Romania, Croatia, Greece and Slovenia, which they divided into two groups based on the time when they joined the EU. Moreover, Jun et al. [26] applied a wavelet tool intending to examine the impact of foreign investments on $\mathrm{CO}_{2}$ and sulfur dioxide (SO2) in China. The results showed that FDIs have created pollution havens in this country. Similarly, Kumar and Chander [27] concluded that India is a shelter for foreign polluters.

Second, the regression results did not support the second hypothesis, H2. Multiple coefficients of determination were calculated by countries and for all countries together, and there were different trends in the region for the dependence of $\mathrm{CO}_{2}$ emissions and GDP, and it was not possible to accept the claim that with increased GDP, $\mathrm{CO}_{2}$ emissions grow as well to a certain point, after which the GDP increase causes a decrease in $\mathrm{CO}_{2}$ emissions. Table 3, where the mean values of each variable are ranked, shows that no country showed consistency in ranking and the ranks by variables differ greatly by countries and for all countries together. The analyzed period from 1998 to 2019 was not suitable for determining the U-trend because the data were missing for some variables and it was not possible to obtain them. Also, Pearson correlation for years and GDP by country and all countries determined that GDP in all countries has a growing trend by year, except in Greece, where a negative annual trend of GDP was recorded. This result for Greece should come as no surprise given that Greece suffered a major financial crisis caused by structural problems [71]. Similar to ours, the results of research by Mor and Jindal [48] showed that, in the case of Romania, Croatia, and Bulgaria, there was not a U-shaped connection with a minimum turning point, so the ECK hypothesis was rejected. The authors also applied a quadratic linear regression model. Several studies $[29,50,51]$ have in common the absence of inverse U-shaped curve in the case of Greece. Škrnjarić [72] in Croatia did not find EKC for the observed pollutants (CO, $\mathrm{CO}_{2}, \mathrm{SO}_{2}$, and PM10), however, the observed period was very short (2008-2016). Moreover, the author stated that the pollution was reduced when Croatia joined the EU. 'No EKC' outcome was also confirmed by Dogan and Inglesi-Lotz [73]. The study was conducted on the example of 7 European countries, including Bulgaria, and confirmed that there is not valid EKC hypothesis in the case of these countries, when their industrial share is used as a proxy to capture the economic structure of a country.

Third, we briefly looked at $\mathrm{CO}_{2}$ emissions in the Balkans and gave an overview of the situation and trends of foreign investment. The trends of FDI inflows turned out to be uneven, with a similar situation in the case of $\mathrm{CO}_{2}$ emissions, although with not so pronounced inequalities. We found that the average values of $\mathrm{CO}_{2}$ emissions per capita in the HIC are consistently higher than the average values in the UMIC, with a reduction in the difference in recent years.

When considered individually, Serbia seems to provide a pollution haven, as the correlation of FDI and $\mathrm{CO}_{2}$ is positive and statistically significant. Over the last two decades, Serbia has adopted a set of "green" laws that have brought it closer to reaching the desired environmental standards. However, Serbia still has a long way to go in terms of environmental protection, especially in the areas of climate change, air quality, waste management, and financing [74]. Since 2011, Albania has adopted a large number of 
modern environmental laws, as part of the EU accession process. However, it is necessary to adopt some subsidiary acts, as well as to fully implement the legislation in this area [75], so this country is still considered a suitable shelter for foreign polluters with a positive and statistically significant correlation of FDI and $\mathrm{CO}_{2}$. As for Bosnia and Herzegovina and Greece, the correlation between FDI and $\mathrm{CO}_{2}$ is negative, which is good, but not statistically significant. In Bosnia and Herzegovina, air pollution and climate change represent significant problems. As a consequence of industrial, domestic, and air emissions from the growing number of vehicles, numerous health problems arise, so this country would have to seriously work on its environmental legislation and embark on the ecological path [76]. Greece's carbon intensity level is still high compared to the other EU members. Bulgaria is also a pollution haven and the correlation between FDI and $\mathrm{CO}_{2}$ is positive and statistically significant. According to the Sustainable Development Report 2019 [77], Bulgaria still has major challenges to overcome to achieve sustainable development goals in the climate sectors and clean and affordable energy. Similar to Bulgaria, Romania is a shelter for foreign polluters as well with a positive statistically significant correlation between FDI and $\mathrm{CO}_{2}$. Although Romania has implemented EU environmental requirements, their implementation is suboptimal in certain areas. Romania's main challenges are lack of administrative capacity, urban wastewater, and poor air quality [78]. Another good haven for foreign polluters is Croatia, with a positive and statistically significant correlation between FDI and $\mathrm{CO}_{2}$. Croatia has adopted the 'Energy Development Strategy until 2030 with an outlook to 2050', which anticipates that total EC will have decreased by 2050, the use of renewable energy sources will increase, and the process of changing fossil fuels for other forms of energy will continue [79]. North Macedonia and Slovenia have a positive correlation between FDI and $\mathrm{CO}_{2}$, which leads to pollution, but the good news is that this correlation is not statistically significant in the case of these two countries. North Macedonia is vulnerable to climate change, especially to extreme weather events, because it still lacks an optimal policy framework and human and technical capacities [80]. When it comes to Slovenia, current environmental problems are high carbon footprint, unsustainable use of land, and poor air quality [81].

The obtained results can be related to the previous theoretical knowledge and most research findings which indicate that, in most cases, investors from countries with high living standards and strict environmental protection legislation see countries with lower living standards and environmental regulations as possible pollution shelters, as well as the EKC upstrokes have fragile statistical substruction.

\section{Conclusions}

This study confirms that the Balkan countries are shelters for foreign polluters, that is, their 'weaker' environmental legislation, among other factors, attracts FDIs that bring environmental pollution along with economic growth. Also, the EKC hypothesis was not confirmed in the Balkan countries. Since economic growth at the expense of the environment does not lead to success in the long run, the Balkan countries should make effort to attract 'green' FDIs to technology-intensive industries through subsidies and other relating measures. Moreover, the Balkan countries should introduce a carbon tax and increase the existing environmental taxes, adopt new, stricter regulations, effectively implement regulations that have already been enforced, adopt EU environmental standards for countries wishing to join the EU, and turn to renewable energy sources. When observed individually, although still not a member of the EU, Montenegro has excellent environmental legislation that has presumably contributed to its title of 'ecological halo'. All Balkan countries still need FDIs to keep pace with the highly developed countries of Western Europe and the world, so optimal solutions and balances should be found between the needs for economic growth on the one hand, and the need for low-carbon development on the other, because both aspects are important for better living standards.

To the best of the authors' knowledge, there have been no scientific studies of the aforementioned hypotheses tested on the group of Balkan countries, which are often 
considered the Balkans as a whole. Thus, it was not possible to perceive the results of this paper in relation to the results of other authors on the Balkans, but it was possible to perceive it in relation to a number of countries within the group. The limitations of this study are reflected in the unavailability of certain data for some countries, and the insufficient number of empirical research focused on this problem and this group of countries. Our study is primarily a group-country study. Bearing that in mind, this manuscript contributes to a better understanding of the environmental aspect of FDIs. Although studies conducted on the samples of individual countries are important, we suggest that future researchers, especially those from the observed countries, should pay additional attention to the Balkans as a region because of thee multiple interconnections between these countries. Also, a more comprehensive model may be used in the future which could include additional variables, such as other GHGs, ecological expenditures, market openness, sectoral FDI, population, etc.

Author Contributions: Conceptualization, A.P., A.I., M.R., and M.N.; methodology, A.P., A.T., and A.L.; formal analysis, A.T.; investigation conducted, A.P., M.N., A.I., and S.K.; writing-original draft preparation by A.P., A.I., M.N., and M.R.; writing-review and editing by A.P., A.L., A.I., and M.N.; supervision by S.K. and M.R. All authors have read and agreed to the published version of the manuscript.

Funding: This research received no external funding.

Institutional Review Board Statement: Not applicable for studies not involving humans or animals.

Informed Consent Statement: Not applicable for studies not involving humans.

Data Availability Statement: The authors declare that the used databases are open access World Bank and International Energy Agency database series (2020).

Conflicts of Interest: The authors declare no conflict of interest.

\section{Appendix A}

Table A1. World Bank's official classification of countries by income group.

\begin{tabular}{cc}
\hline HIC $\mathbf{( \$ 1 2 , 5 3 6 ~ O R ~ M O R E ) ~}$ & UMIC $\mathbf{( \$ 4 0 4 6}$ TO $\$ \mathbf{1 2 , 5 3 5 )}$ \\
\hline Croatia & Serbia \\
Greece & Montenegro \\
Romania & Albania \\
Slovenia & Bosnia and Herzegovina \\
& North Macedonia \\
& Bulgaria \\
\hline
\end{tabular}




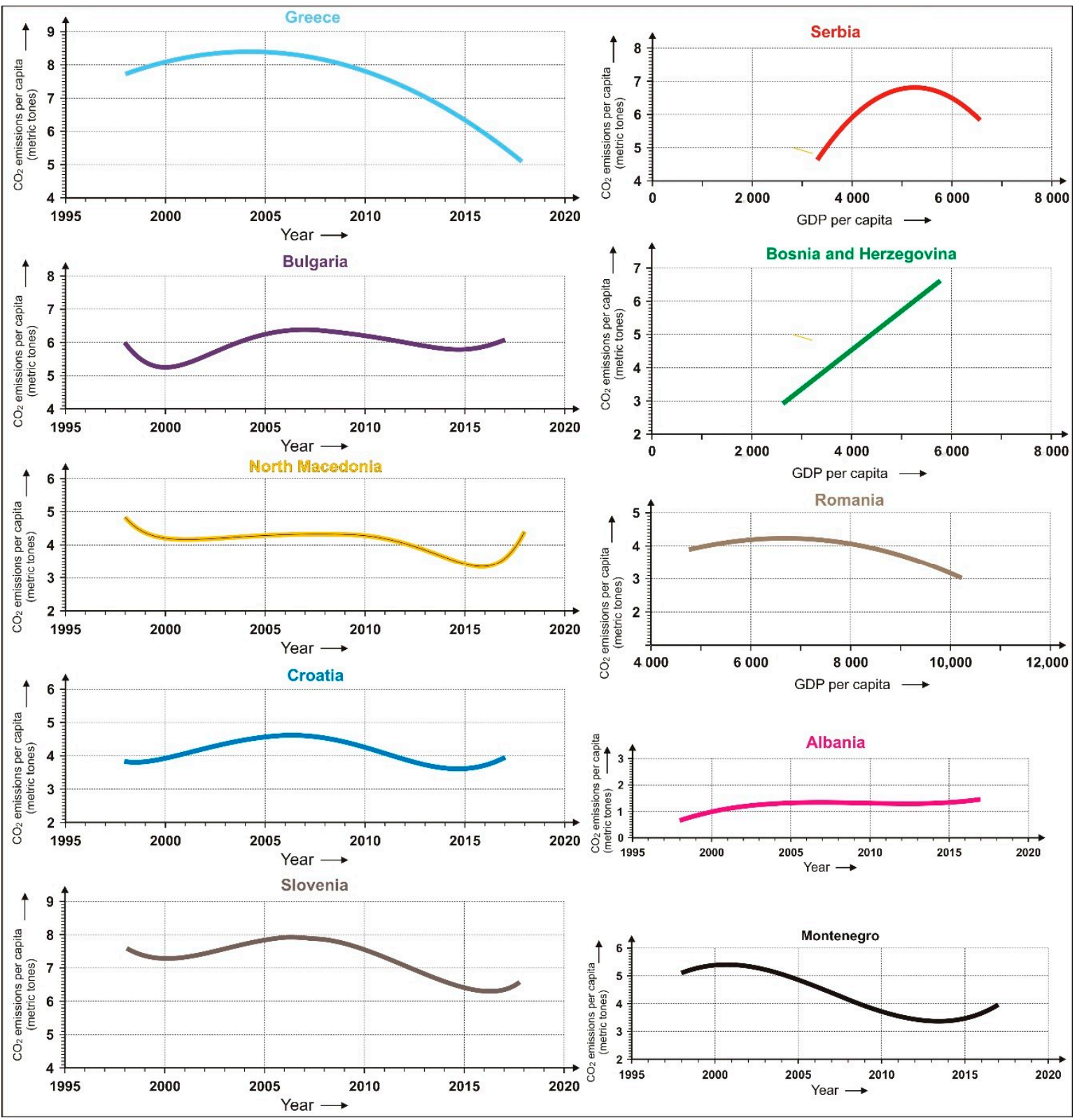

Figure A1. Relationship between $\mathrm{CO}_{2}$ emissions per capita and GDP per capita in each of the ten Balkan countries (1998-2019) (Authors' creation).

\section{References}

1. Freckleton, M.; Wright, A.; Craigwell, R. Economic growth, foreign direct investments and corruption in developed and de-veloping countries. J. Econ. Stud. 2012, 39, 639-652. [CrossRef]

2. Owusu-Nantwi, V.; Erickson, C. Foreign direct investment and economic growth in South America. J. Econ. Stud. 2019, 46, 383-398. [CrossRef]

3. Cvetanović, S.; Mladenović, I. Capital Economics and Development Finance; 2013; pp. 277-282, ISBN 978-86-910765-2-8. Available online: https:/ /www.researchgate.net/publication/292654969_Economic_development_finance (accessed on 21 November 2020)

4. Kaur, M.; Yadav, S.S.; Gautam, V. A bivariate causality link between foreign direct investment and economic growth: Evidence from India. J. Int. Trade Law Policy 2013, 12, 68-79. [CrossRef]

5. Lehnert, K.; Benmamoun, M.; Zhao, H. FDI inflow and human development: Analysis of FDI's impact on host countries' social welfare and infrastructure. Thunderbird Int. Bus. Rev. 2013, 55, 285-298. [CrossRef]

6. Wang, X.; Luo, Y. Has technological innovation capability addressed environmental pollution from the dual perspective of FDI quantity and quality? Evidence from China. J. Clean. Prod. 2020, 258, 120941. [CrossRef]

7. Hansen, H.J.; Rand, J. On the causal links between FDI and growth in developing countries. World Econ. 2006, 29, 21-41. [CrossRef] 
8. Rapaić, S.I. The Role of Foreign Direct Investment in Local Economic Development in Republic of Serbia (2001-2013). Ph.D. Thesis, University of Belgrade, Belgrade, Serbia, 2016.

9. Mallett, J.; Keen, C. Does GDP measure growth in the economy or simply growth in the money supply? arxiv 2012, arXiv:1208.0642.

10. Ntantanis, H.; Pohlman, L. Market implied GDP. J. Asset Manag. 2020, 21, 636-646. [CrossRef]

11. Mladenović, I.; Sokolov-Mladenović, S.; Milovančević, M.; Marković, D.; Simeunović, N. Management and estimation of thermal comfort, carbon dioxide emission and economic growth by support vector machine. Renew. Sustain. Energy Rev. 2016, 64, 466-476. [CrossRef]

12. UNCTAD. World Investment Report 2020: International Production Beyond the Pandemic; UN: New York, NY, USA, 2020. Available online: https:/ / doi.org/10.18356/920f7642-en (accessed on 21 November 2020).

13. Taub, D.R.; Miller, B.; Allen, H. Effects of elevated $\mathrm{CO}_{2}$ on the protein concentration of food crops: A meta-analysis. Glob. Chang. Biol. 2008, 14, 565-575. [CrossRef]

14. Government of the Republic of Serbia and United Nations Country Team in Serbia. Development Partnership Framework 2016-2020; Belgrade, Serbia, 2017; p. 31. Available online: https://serbia.un.org/sites/default/files/2019-08/DPF_ENG_30_May_2017 _FINAL_SIGNED.pdf (accessed on 11 November 2020).

15. Eurostat. Available online: https://ec.europa.eu/eurostat/statisticsex-plained/index.php/GDP_per_capita,_consumption_ per_capita_and_price_level_indices (accessed on 3 December 2020).

16. Unctadstat. Available online: https://unctadstat.unctad.org/en/Classifications/DimCountries_DevelopmentStatus_Hierarchy. pdf (accessed on 21 November 2020).

17. World Bank. World Development Indicators 2016; World Bank: Washington, DC, USA, 2016. [CrossRef]

18. Demena, B.A.; Afesorgbor, S.K. The effect of FDI on environmental emissions: Evidence from a meta-analysis. Energy Policy 2020, 138, 111192. [CrossRef]

19. Kearsley, A.; Riddel, M. A further inquiry into the pollution haven hypothesis and the environmental kuznets curve. Ecol. Econ. 2010, 69, 905-919. [CrossRef]

20. Nestorović, O. Foreign Direct Investment as a Factor of Sustainable Development of Serbian Economy. Ph.D. Thesis, University of Kragujevac, Kragujevac, Serbia, 2015.

21. Öztürk, Z. The Relationship between Energy Consumption, Income, Foreign Direct Investment, and $\mathrm{CO}_{2}$ Emissions: The Case of Turkey. Çankırı Karatekin Univ. İIBF Derg. 2016, 6, 1. [CrossRef]

22. Mert, M.; Bölük, G. Do foreign direct investment and renewable energy consumption affect the CO2 emissions? New evidence from a panel ARDL approach to Kyoto Annex countries. Environ. Sci. Pollut. Res. 2016, 23, 21669-21681. [CrossRef] [PubMed]

23. Zhang, C.; Zhou, X. Does foreign direct investment lead to lower $\mathrm{CO}_{2}$ emissions? Evidence from a regional analysis in China. Renew. Sustain. Energy Rev. 2016, 58, 943-951. [CrossRef]

24. Neves, S.A.; Marques, A.C.; Patrício, M. Determinants of CO2 emissions in European Union countries: Does environmental regulation reduce environmental pollution? Econ. Anal. Policy 2020, 68, 114-125. [CrossRef]

25. Acharyya, J. FDI, growth and the environment: Evidence from india on $\mathrm{CO}_{2}$ emission during the last two decades. J. Econ. Dev. 2009, 34, 43-58. [CrossRef]

26. Jun, W.; Zakaria, M.; Shahzad, S.J.H.; Mahmood, H. Effect of FDI on pollution in China: New insights based on wavelet approach. Sustainability 2018, 10, 3859. [CrossRef]

27. Kumar, V.; Chander, R. Foreign direct investment and air pollution: Granger causality analysis. IOSR J. Bus. Manag. 2016, 12, 2319-7668. [CrossRef]

28. Koçak, E.; Şarkgüneşi, A. The impact of foreign direct investment on $\mathrm{CO}_{2}$ emissions in Turkey: New evidence from cointegration and bootstrap causality analysis. Environ. Sci. Pollut. Res. 2018, 25, 790-804. [CrossRef]

29. Mert, M.; Bölük, G.; Çağlar, A.E. Interrelationships among foreign direct investments, renewable energy, and CO2 emissions for different European country groups: A panel ARDL approach. Environ. Sci. Pollut. Res. 2019, 26, 21495-21510. [CrossRef] [PubMed]

30. Solarin, S.A.; Al-Mulali, U. Influence of foreign direct investment on indicators of environmental degradation. Environ. Sci. Pollut. Res. 2018, 25, 24845-24859. [CrossRef] [PubMed]

31. Al Shubiri, F.N.; Elheddad, M. Foreign finance, economic growth and $\mathrm{CO}_{2}$ emissions Nexus in OECD countries. Int. J. Clim. Chang. Strat. Manag. 2019, 12, 161-181. [CrossRef]

32. Marques, A.C.; Caetano, R. The impact of foreign direct investment on emission reduction targets: Evidence from high- and middle-income countries. Struct. Chang. Econ. Dyn. 2020, 55, 107-118. [CrossRef]

33. Chang, C.-C. A multivariate causality test of carbon dioxide emissions, energy consumption and economic growth in China. Appl. Energy 2010, 87, 3533-3537. [CrossRef]

34. Salahuddin, M.; Gow, J. Economic growth, energy consumption and $\mathrm{CO}_{2}$ emissions in Gulf Cooperation Council countries. Energy 2014, 73, 44-58. [CrossRef]

35. Li, R.; Jiang, H.; Sotnyk, I.; Kubatko, O.; Almashaqbeh, I.Y.A. The $\mathrm{CO}_{2}$ Emissions Drivers of Post-Communist Economies in Eastern Europe and Central Asia. Atmosphere 2020, 11, 1019. [CrossRef]

36. Hatzigeorgiou, E.; Polatidis, H.; Haralambopoulos, D. $\mathrm{CO}_{2}$ emissions, GDP and energy intensity: A multivariate cointegration and causality analysis for Greece, 1977-2007. Appl. Energy 2011, 88, 1377-1385. [CrossRef] 
37. Mitić, P.; Ivanović, O.M.; Zdravkovic, A. A cointegration analysis of real GDP and $\mathrm{CO}_{2}$ emissions in transitional countries. Sustainability 2017, 9, 568. [CrossRef]

38. Petrović, P.; Nikolić, G.; Ostojić, I. Emissions of $\mathrm{CO}_{2}$ in the European Union: Empirical analysis of demographic, economic and technological factors. Stanovništvo 2018, 56, 63-82. [CrossRef]

39. Kuznets, S. Economic growth and income inequality. Am. Econ. Rev. 1955, 45, 1-28.

40. Grossman, G.M.; Krueger, A.B. Environmental Impacts of a North. American Free Trade Agreement; NBER Working Papers 3914; National Bureau of Economic Research: Cambridge, MA, USA, 1991.

41. Tiwari, A.K.; Shahbaz, M.; Muhammad, Q.; Hye, A. The environmental Kuznets curve and the role of coal con-sumption in India: Cointegration and causality analysis in an open economy. Renew. Sust. Energ. Rev. 2013, 18, 519-527. [CrossRef]

42. Pata, U.K. Renewable energy consumption, urbanization, financial development, income and CO2 emissions in Turkey: Testing EKC hypothesis with structural breaks. J. Clean. Prod. 2018, 187, 770-779. [CrossRef]

43. Seker, F.; Ertugrul, H.M.; Cetin, M. The impact of foreign direct investment on environmental quality: A bounds testing and causality analysis for Turkey. Renew. Sustain. Energy Rev. 2015, 52, 347-356. [CrossRef]

44. Pao, H.-T.; Yu, H.-C.; Yang, Y.-H. Modeling the $\mathrm{CO}_{2}$ emissions, energy use, and economic growth in Russia. Energy 2011, 36, 5094-5100. [CrossRef]

45. Naz, S.; Sultan, R.; Zaman, K.; Aldakhil, A.M.; Nassani, A.A.; Abro, M.M.Q. Moderating and mediating role of renewable energy consumption, FDI inflows, and economic growth on carbon dioxide emissions: Evidence from robust least square estimator. Environ. Sci. Pollut. Res. 2019, 26, 2806-2819. [CrossRef] [PubMed]

46. Mor, S.; Jindal, S. Estimation of environmental kuznets curve and kyoto parties: A panel data analysis. IJCEM 2012, 15, 5-9.

47. Shahbaz, M.; Mutascu, M.; Azim, P. Environmental Kuznets curve in Romania and the role of energy consump-tion. Renew. Sust. Energ. Res. 2013, 18, 165-173.

48. Kotroni, E.; Kaika, D.; Zervas, E. Environmental kuznets curve in greece in the period 1960-2014. Int. J. Energy Econ. Policy 2020, 10, 364-370. [CrossRef]

49. Bozoklu, S.; Demir, A.O.; Ataer, S. Reassessing the environmental Kuznets curve: A summability approach for emerging market economies. Eurasian Econ. Rev. 2020, 10, 513-531. [CrossRef]

50. Mitić, P.; Kostić, A.; Petrović, E.; Cvetanović, S. The relationship between $\mathrm{CO}_{2}$ emissions, industry, services and gross fixed capital formation in the Balkan countries. Eng. Econ. 2020, 31, 425-436. [CrossRef]

51. Gorus, M.S.; Aydin, M. The relationship between energy consumption, economic growth, and CO2 emission in MENA countries: Causality analysis in the frequency domain. Energy 2019, 168, 815-822. [CrossRef]

52. Wang, X.; Huang, C.; Zou, Z. The analysis of energy consumption and greenhouse gas emissions of a large-scale commercial building in Shanghai, China. Adv. Mech. Eng. 2016, 8, 1-8. [CrossRef]

53. Štrbac, N.; Vuković, M.; Voza, D.; Sokić, M. Sustainable development and environmental protection. Recycl. Sustain. Dev. J. 2012, $5,18-29$.

54. Ślusarczyk, B.; Kot, S. Solution for sustainable development: Provisions limiting the consumption of disposable plastic carrier bags in Poland. J. Secur. Sustain. Issues 2018, 7, 449-458. [CrossRef]

55. Hussain, H.I.; Slusarczyk, B.; Kamarudin, F.; Thaker, H.M.T.; Szczepańska-Woszczyna, K. An investigation of an adaptive neuro-fuzzy inference system to predict the relationship among energy intensity, globalization, and financial development in major ASEAN economies. Energies 2020, 13, 850. [CrossRef]

56. Sabishchenko, O.; Rębilas, R.; Sczygiol, N.; Urbański, M. Ukraine energy sector management using hybrid re-newable energy systems. Energies 2020, 13, 1776. [CrossRef]

57. Shafiei, S.; Salim, R.A. Non-renewable and renewable energy consumption and $\mathrm{CO}_{2}$ emissions in OECD coun-tries: A comparative analysis. Energy Policy 2014, 66, 547-556. [CrossRef]

58. Bilgili, F.; Koçak, E.; Bulut, Ü. The dynamic impact of renewable energy consumption on $\mathrm{CO}_{2}$ emissions: A revisited Environmental Kuznets Curve approach. Renew. Sustain. Energy Rev. 2016, 54, 838-845. [CrossRef]

59. Sasana, H.; Putri, A.E. The Increase of Energy Consumption and Carbon Dioxide $\left(\mathrm{CO}_{2}\right)$ Emission in Indonesia. E3S Web Conf. 2018, 31, 01008. [CrossRef]

60. Sharif, A.; Raza, S.A.; Ozturk, I.; Afshan, S. The dynamic relationship of renewable and nonrenewable energy consumption with carbon emission: A global study with the application of heterogeneous panel estimations. Renew. Energy 2019, 133, 685-691. [CrossRef]

61. Heil, M.T.; Wodon, Q.T. Inequality in $\mathrm{CO}_{2}$ emissions between poor and rich countries. J. Environ. Dev. 1997, 6, 426-452. [CrossRef]

62. Padilla, E.; Serrano Mancilla, A. Inequality in $\mathrm{CO}_{2}$ emissions across countries and its relationship with income inequality: A distributive approach. Energy Policy 2006, 34, 1762-1772. [CrossRef]

63. Agras, J.; Chapman, D. A dynamic approach to the Environmental Kuznets Curve hypothesis. Ecol. Econ. 1999, 28, 267-277. [CrossRef]

64. The World Bank. Available online: https://datahelpdesk.worldbank.org/knowledgebase/articles/906519-world-bank-countryand-lending-groups (accessed on 29 December 2020).

65. Shen, L.; Koveos, P.; Zhu, X.; Wen, F.; Liao, J. Outward FDI and Entrepreneurship: The Case of China. Sustainability 2020, 12, 5234. [CrossRef] 
66. Ardakani, M.K.; SeyedAliAkbar, S.M. Impact of energy consumption and economic growth on $\mathrm{CO}_{2}$ emission using multivariate regression. Energy Strat. Rev. 2019, 26, 100428. [CrossRef]

67. Ministry of Sustainable Development and Tourism of Montenegro. National Strategy for Sustainable Development until 2030. Podgorica, 2016. Available online: http:/ / www.nssd2030.gov.me/ (accessed on 24 October 2020).

68. Smarzynska, B.K.; Wei, S. Pollution havens and foreign direct investment: Dirty secret or popular myth? Contrib. Econ. Anal. Policy 2005, 3, 1244.

69. Cai, X.; Che, X.; Zhu, B.; Zhao, J.; Xie, R. Will developing countries become pollution havens for developed coun-tries? An empirical investigation in the Belt and Road. J. Clean. Prod. 2018, 198, 624-632. [CrossRef]

70. Simeunčević, S. Foreign direct investment impact on environment in Serbia in the period 2000-2008. Spatium 2011, 24, 63-70. [CrossRef]

71. Johnston, M.; Understanding the Downfall of Greece's Economy. Investopedia. Available online: https:/ /www.investopedia. com/articles/investing/070115/understanding-downfall-greeces-economy.asp (accessed on 24 October 2020).

72. Škrinjarić, T. Environmental Kuznets Curve in Croatia: Panel data approach with Croatian counties. J. Central Eur. Agric. 2019, 20, 712-740. [CrossRef]

73. Dogan, E.; Inglesi-Lotz, R. The impact of economic structure to the environmental Kuznets curve (EKC) hypothesis: Evidence from European countries. Environ. Sci. Pollut. Res. 2020, 27, 12717-12724. [CrossRef] [PubMed]

74. Coalition 27. Chapter 27 in Serbia: Money Talks; Bird Protection and Study Society of Serbia; Antić, M., Ed.; Belgrade Open School: Belgrade, Serbia, 2019. Available online: https://rs.boell.org/sites/default/files/izvestaj_2019_eng_web.pdf (accessed on 24 October 2020).

75. Tvaronavičienè, M.; Nesterova, K.; Kováčik, V. Energy security and long-term energy efficiency: Case of selected counties. J. Secur. Sustain. Issues 2017, 7, 349-357. [CrossRef]

76. United Nations Economic Commission for Europe. 3rd Environmental Performance Review of Albania. Available online: https: //www.unece.org/fileadmin/DAM/env/epr/epr_studies/Leaflet/Booklet_3rdEPRAlbania.pdf (accessed on 24 October 2020).

77. UN ECE. Environmental Performance Reviews: Bosnia and Herzegovina: Second Review, ECE Environmental Performance Reviews Series, No. 32; UN ECE: Geneva, Switzerland, 2013; Volume 10. [CrossRef]

78. SDSN \& IEEP. The 2019 Europe Sustainable Development Report. Sustainable Development Solutions Network and Institute for European Environmental Policy: Paris and Brussels. 2019. Available online: https://s3.amazonaws.com/sustainabledevelopment. report/2019/2019_europe_sustainable_development_report.pdf (accessed on 24 October 2020).

79. The EU Environmental Implementation Review 2019. Country Report-Romania. Available online: https://ec.europa.eu/ environment/eir/pdf/report_ro_en.pdf (accessed on 24 October 2020).

80. Drăghici, C.C.; Andronache, I.; Ahammer, H.; Peptenatu, D.; Pintilii, R.-D.; Ciobotaru, A.-M.; Simion, A.G.; Do-brea, R.C.; Diaconu, D.C.; Vișan, M.-C.; et al. Spatial evolution of forest areas in the northern Carpathian mountains of Romania. Acta Montan. Slovaca 2017, 22, 95-106.

81. Summary of the Commission Assessment of the Draft National Energy and Climate Plan 2021-2030. Available online: https: / / ec.europa.eu/energy/sites/ener/files/documents/necp_factsheet_ro_final.pdf (accessed on 18 October 2020). 